\title{
THE AFRIKANDER VOLUNTEER CORPS AND THE PARTICIPATION OF AFRIKANERS IN CONFLICTS IN RHODESIA, 1893-1897
}

\author{
Gustav Hendrich \\ Department of History, Stellenbosch University
}

\begin{abstract}
During the last decade of the nineteenth century, British colonisation in Southern Africa, in particular in Rhodesia (today Zimbabwe) had coincided with uneasy relations with the native black population. Partly because of continuing disillusionment over stringent policy regarding native livestock, hostilities between the colonial officials and Matabele and Mashona tribal groups resulted in devastating wars. Within these warring circumstances, Afrikaner settlers who had immigrated to Rhodesia since 1891 - mostly in search of better living opportunities - subsequently found themselves amidst the crossfire of these conflicts. Though subjugated to British colonial authority, the Afrikaner minority were regarded by native blacks as collaborators in maintaining white military and political power in Rhodesia.

Consequently, the mere safety of Afrikaners were threatened by sporadic military attacks and skirmishes during the Anglo-Matabele war of 1893, and most of all, for the duration of the Matabele and Mashona rebellions of 1896 to 1897. During the Matabele rebellion, an Afrikander Volunteer Corps (known as the Afrikaner Korps) was established as a military unit, which provided substantial support in two decisive battles. This article seeks to address the role and history of the Afrikander Volunteer Corps, as well as the involvement of ordinary Afrikaners in the turbulent colonial wars in early Rhodesia.
\end{abstract}

\section{Introduction}

Unfavourable states of war occurred more or less simultaneously with the arrival in Rhodesia of the first Afrikaner treks. Increasing enmity between the

Scientia Militaria, South African Journal of Military Studies, Vol 40, Nr 1, 2012, pp. 25-48. doi: $10.5787 / 40-1-983$
British colonialists and the traditional indigenous population groups, the Matabele and the Mashona, which centred mainly on an intense power struggle and local dissatisfaction, soon led to war. In the first ten 
years of British control in Rhodesia, the gradual development, white settlement and consolidation of power were greatly hampered by continual local and regional wars. In this article, which arises from the author's doctoral study of the Afrikaners in Rhodesia, the effect of these conflicts on the Afrikaners and their participation in Rhodesian military forces is explored. ${ }^{1}$

\section{Participation in auxiliary and voluntary military units in historical context}

It is of cardinal importance to understand the context and causes leading to the formation of auxiliary and voluntary military forces before the participation of Afrikaners in military conflicts in early Rhodesia can be examined. In a study by W.G.J. Iemhoff dealing with the philosophical questions relating to conscription and modern warfare, the point of view is that it is in the first instance the individual's rightful choice to become involved with military forces or not. According to Iemhoff, the intrinsic priorities of conscripts to defend a state are determined in order to ensure freedom and to "guarantee humanity in a society". ${ }^{2}$ Various other causal reasons, amongst others political, socio-economical, cultural and religious, can be advanced for the enlistment of individuals or factions of minorities. Subjacent to the above reasons it can be argued that these units are formed principally for three reasons, i.e. necessity, free choice or compulsion.

In military-historic context military units, especially those comprising minority groups in a host country are often raised because of the threat of overpowering enemy forces. An example of military units, which were disposed to defend the dominant military forces or order of the host country because of a sense of necessity, is the Irish paramilitary unit, known as the Ulster Volunteer Force. Before and during the Irish Easter Uprising in Dublin in 1916, Irish volunteers belonging to the Ulster Volunteer Force proved their loyalty to the British crown. ${ }^{3}$ Although it can be argued at the same that they also joined of their own free will, many Irish loyalists were of the opinion that Ireland should remain indissolubly part of the British Empire. As another example, during the Second World War, the socalled "Gurkhas", a battalion consisting of British Nepalese troops, played a decisive role in the defence of India and against the Japanese invasion of Burma.

Military units or auxiliary forces were formed through free choice or decisions, and they joined friendly or even accommodating enemy occupation forces. During the Second World War, inter alia, units of the so-called Vichy French, and especially the Cossack unit under the command of General Andrey Vaslov, joined the Nazi German occupation forces as collaborators. ${ }^{4}$ The Cossack 
unit placed their hope in "liberation" by Nazi Germany mainly because of deepseated factors such as the dissatisfaction caused by the derogation of the past after the Russian Civil War and the terror of Stalin's purges. ${ }^{5}$ After the fall of Nazi Germany in 1945, these Cossacks were likewise regarded as traitors and vengefully repatriated to the Soviet Union.

In spite of their harsh treatment initially, after 1941, Americans of Japanese origin performed military duty in the European war theatre in a patriotic manner in two segregated units, namely the $100^{\text {th }}$ Infantry Battalion and the $442^{\text {nd }}$ Regimental Combat Team. Japanese Americans also served as interpreters in the so-called Nisei unit of the intelligence service in the war against Japan. ${ }^{6}$

The third underlying cause of individuals joining military units in the host state is that of compulsion. Mainly as a result of the implementation of compulsory conscription laws and policy regulations, members of minority groups especially were forced to perform military service. During the First World War, many Kurdish soldiers in the Ottoman forces were called up for military service. Although Kurdish military support on the Turkish war fronts (and especially in the Battle of Sarikamish) was significant, there was among the Kurdish recruits a reticence, disapproval and even refusal to participate actively in the war. Ironically, the Kurdish soldiers would, after the collapse of the Ottoman Empire, be systematically deported and resettled by the Turkish forces that held them co-responsible for the Armenian genocide. ${ }^{7}$ Comprehensively viewed, these three underlying causes therefore led to the formation of separate military units and in no small measure played an important role in the circumstances of war.

In the context of Southern Africa during the era of colonisation, the formation of volunteer forces or units in support of the colonial powers had been largely impelled by compulsion and free will. In South Africa, a fixed law pertaining to the regulations and establishment of volunteer forces was enacted. In compliance with the Colonial Forces Act of 1892, every voluntary force or military unit stood under the authority of the governor. The Act stated that units raised in sparsely populated districts had to consist of at least 30 members, and that the governor could decide on its formation or disbandment. ${ }^{8}$ As enrolment was purely of a voluntary nature, these volunteers could simply choose to quit by giving one month's notice with reasons for quitting. ${ }^{9}$ Nonetheless, members who were liable to serve after being enrolled and who were thereafter found guilty of contravening the abovementioned Act, could be penalised for up to $£ 10$ for misconduct. ${ }^{10}$ Although it appeared to be a casual or merely supportive military force, it is evident that there 
were strict regulations according to the law governing participants within these forces.

Before and during the Anglo-Zulu War of 1878 in Natal, various voluntary forces were formed under the auspices of the governor. According to an analysis by Colonel Godfrey Hurst of the volunteer regiments in Natal and Griqualand East, a multitude of volunteer or auxiliary units was formed as a defensive measure against possible Zulu hostilities. In the case of the Port Natal Volunteers, which was established in 1837, an unknown number of indigenous people were enrolled in the force alongside of European volunteers and non-commissioned officers who had the desire to protect their families and relatives from military threats. ${ }^{11}$ The Natal Voluntary Force was, for instance, called upon to defend the Tugela River by patrolling the river frontier. After the British defeat at the battle of Isandhlwana, an order was given for the formation of auxiliary forces, such as the Isipingo Mounted Rifles and the Escombes' Contingent with the sole purpose of guarding the Tugela River. ${ }^{12}$ Many of these forces were disbanded after the war with volunteers returning home, while others, such as the Umvoti Mounted Rifles at Greytown, continued to maintain law and order in the countryside of Natal.

\section{The Anglo-Matabele War of 1893}

After the arrival of the Pioneer column in 1890, major political and administrative changes occurred, which were aimed at structuring the new "British colony" according to the principles of Western civilisation. English, people of European descent and Afrikaners were welcomed and encouraged to relocate to Rhodesia on the strict condition that British colonial legislation was to be obeyed. Initially, the Matabele under Lobengula were favourably disposed towards the British rulers, but as the rule gained more stature, relations became more hostile. Intolerance of the social and political systems and conduct increased. The Afrikaners, with their views of racial superiority, took the side of the British.

At the end of the 19th century, the racial attitudes of Afrikaners were no different from other European and British perceptions. As a result of the gradual evolution of a racist ideology amongst the majority of Europeans, there was a strong belief that white culture was inherently superior to that of the rest of the world. This belief was fuelled primarily by imperialists who sought to legitimise both imperialism and the control and dissolution of indigenous peoples. Europeans also considered it their duty or humanitarian obligation to Christianise and civilise these peoples. Rudyard Kipling's controversial poem, “The white man's burden”, remains a pivotal illustration of the racial ideology, which underlines the preconceptions, and 
attitudes of white racial prejudice. ${ }^{13}$ In addition to the religious work of the London Missionary Society and the Wesleyan and Methodist denominations, the Afrikaner missionaries of the Dutch Reformed Church also sought to spread the Christian Gospel amongst the Mashona and Matabele peoples. L.H. Gann, the famous chronicler of Rhodesian history, pointed out that Afrikaner missionaries had long been eager to evangelise the north, but that Lobengula "did not like the idea of European missionaries teaching within his sphere of influence". ${ }^{14}$ In spite of this, Rev A.A. Louw established the Morgenster ("Morning Star") missionary station in Rhodesia with a view to bringing the Christian Calvinist religion to the indigenous people.

For the Matabele tribe, the causes of the friction and eventual outbreak of the war lay in the difference between social structures. On the one hand, the Matabele's social structure was based on the looting and domination of neighbouring Mashona tribes. On the other hand, the British government utterly disapproved of this practice because of the threat to property and sources of labour that it posed. ${ }^{15}$ Both the leaders of the warring factions, namely L.S. Jameson and Lobengula, did everything possible to prevent the war. Lobengula could, however, not control the irrepressible rebelliousness among the younger Matabele warriors or "matjaka". Archibald Colquhoun, a British government official and special war correspondent, claimed that Lobengula was powerless to prevent possible attacks on Europeans by the impi. ${ }^{16}$ In time, even Lobengula fell into disfavour, also among the Afrikaners, as was reported in Di Afrikaanse Patriot:

... but Lobengula sought to play off Boer and Englishman against each other by deliberately misleading politics. He was not diplomatic enough for this; he became a victim of British politics. If he had, like his father [Mzilikazi] remained entirely on the side of the Boers, he would still be in possession of his kingdom today. ${ }^{17}$

During 1893, several skirmishes and incidents took place in Matabeleland, including the raiding of Mashona livestock and the theft of a British telegraph line. The Fort Victoria incident, in which raiding Matabeles attacked the Mashona and besieged the white settlers, was the trigger to the war. ${ }^{18}$ The Anglo-Matabele war between the Matabele and pioneers of the British South Africa Company (BSAC) broke out in October 1893. An urgent call to end the "Matabele threat" was made in British circles. English pioneers and Afrikaner volunteers were compelled by circumstances to join the BSAC. The total number of Afrikaners involved in the military forces is unknown, although noteworthy mention was made of an imposing Afrikaner, Commandant Pieter Johannes Raaff. Comdt. Raaff, who was appointed 
by the British to muster a troop of 250 mounted men in Pretoria, would play a significant part in the effort to capture Lobengula. ${ }^{19}$ The volunteers would receive about 10/- per day, with food supply, weapons and ammunition, as well as a farm in Rhodesia as remuneration. Furthermore, the stipulation was that, if victory was gained, half the spoils (especially livestock and poultry) would be allocated to the BSAC and the other half to the volunteers. ${ }^{20}$

The intensity of the war escalated. Thousands of Matabele warriors or impi battled bravely against the European military forces with assegais. The Matabele suffered great losses at the hands of the pioneer troops who were armed with firearms and Maxim machine-guns. Following a bitter battle at Bulawayo where, among other things, Lobengula's royal kraal was situated, Lobengula was ousted after an ammunition magazine was destroyed in a terrific explosion.

During the pursuit of the fleeing Lobengula, one of the most famous events from a Rhodesian perspective occurred at the Shangani River. One Du Plessis, an Afrikaner who gave an account of his experiences, was in contact with Captain Allan Wilson shortly before the incident. Du Plessis warned Wilson not to swim across the Shangani River, as the Matabele could easily take them by surprise. Du Plessis told how he fortuitously escaped the impending tragedy because Sagrys le Roux commandeered him, at the request of Rhodes, to escort a convoy to Tuli. ${ }^{21}$ In the pursuit of Lobengula, Wilson and his patrol ignored unit instructions to advance on Lobengula with Captain P.W. Forbes. The floodwaters of the Shangani River trapped the unit, and at daybreak on 4 December 1893, they were surrounded by Lobengula's personal force. ${ }^{22}$

A great many Matabele were killed in the dramatic attack, but Wilson's force was overpowered by the Matabeles' numerical strength. The patrol fought courageously but in vain in the battle, which became known as "the Last Stand". The entire patrol of 33 men, including Wilson, was murdered. It was a narrow escape for Du Plessis, who had left them only half an hour earlier. ${ }^{23}$ On the nameplate of the fallen at the Shangani memorial in the Matopos, it appears (speculatively) that two Afrikaners, a Private De Vos, and a Lieutenant Hofmeyer, were part of Wilson's patrol.

After the incident, the Matabele military force fell into confusion and was then systematically dominated by the British. However, the entire power base of the Matabele had not been completely broken. The war had negative long-term consequences because, according to Anna Dorey, it transformed the "occupation 
into a victory" and muddied the relations between pioneers, Afrikaners and the Matabele. $^{24}$

\section{The Matabele and Mashona rebellions}

By 1896, the Matabele tribe had once more become restless as a result of the stricter enforcement of measures and regulations by the British company control. In spite of their defeat in the Matabele war, the core of the Matabele warriors never accepted the fact that their military force had crumbled. Their grievances and unhappiness reached breaking point when the BSAC adopted a stringent measure. Pests and plagues ravaged Rhodesia, but it was specifically the effect of rinderpest on livestock and the resulting decision of British officials to destroy infected livestock on a large scale in order to prevent the spread of the disease that was the proverbial spark in the powder keg. ${ }^{25}$ Because their livestock was their sole form of prosperity, the Matabele could not understand this impulsive destruction and indeed held the whites responsible for the death of their stock. In March 1896, in reprisal and partly because of the British failure in the Jameson Raid (as well as the underlying suspicion that they could well be beaten) the Matabele began to rebel against the whites en masse.

Post-colonial literature after 1980 dealing with the early history of Rhodesia is in stark contrast to white perspectives regarding the causes or motives for the rebelliousness of the Matabele and Mashona tribes. Historiographically, the black indigenous tribes saw the causal reasons for the outbreak of the rebellions in an entirely different light. In a co-study entitled Voices of Zimbabwe, G. Hunter, L. Farren and A. Farren brought the traditional black Zimbabwean viewpoint to the fore. According to their study, the fundamental reason for the rebellions was the general opinion of the black people that the white settlers under Rhodes had cheated them badly or placated them in order to take possession of their territory. ${ }^{26}$ At the same time Ruth Weiss, the subsequent author of Zimbabwe and the new elite, also points out that the Matabele became, as it were, squatters in their erstwhile territory. ${ }^{27}$ Further immediate causes which could be advanced are probably the loss of livestock after a serious drought and the threat of famine. Secondly, there was the real threat of white men to, among others, Mashona women because of the relatively small number of white women. Black women were regarded as the most vulnerable group, because they were often abducted, exploited or could be used as women for their white colonial rulers or collaborators in order to force black warriors to surrender. ${ }^{28}$ Thirdly, the employment of some black people within the BSAC resulted in their assistance in terrorising the local black population before the 
rebellion. Fourthly, the BSAC's introduction of hut tax in 1894 led to great grievances and inconvenience.

Furthermore, private ownership and taxes were totally alien concepts to the black populations because their territory, specifically according to their ancestral beliefs, belonged to them legitimately. According to Weiss, this conviction was strengthened by their ancestor worship. Because of the pronouncements of the socalled Mwari priests (who acted as intermediaries between the individual and the spirits) that the whites would be forced to return to their places of origin, these priests played a spiritual role in inciting the Matabele warriors. ${ }^{29}$ These warriors were ordered to carry out their ancestral instructions without hesitation in the case of certain spiritual desires, for example to resort to extreme violence.

For this reason, Matabele warriors attacked white inhabitants in the rural areas, isolating and torturing or killing them. About forty Afrikaners were declared missing by the headquarters of the BSAC in Bulawayo. ${ }^{30}$ The list of names of missing Afrikaners accentuates the point of view that the Matabele rebellion was not only aimed at the British, but also at Afrikaners.

On 30 April 1896, Townshend Griffin, a British official in the BSAC office in Bulawayo, published a list of names of missing persons in Matabeleland and other districts by way of a communication. Mention was made of forty missing Afrikaners, but in fact, the particulars of only 17 Afrikaners were given. Among the Afrikaners specifically mentioned as being missing in the environs of Bulawayo were Isaac de Villiers, W. de Smidt, John Rothman, one Nieuwenhaus, and John Greyling and his wife and three children. In various other areas, namely Shangani, Gwelo and Salisbury, the following Afrikaners were declared missing by Griffin: one Kramer (prospector), one Van Blerk (miner), one Weinand (stock inspector), one Barnard, one Oosthuizen, P. Roet, T. Botes and Frans Kruger. ${ }^{31}$

Two Afrikaner men, C.H. Fourie and D.R. Potgieter, were murdered in the immediate vicinity of Bulawayo. On 2 April 1896, Stephanus Kruger and his wife and five children were brutally murdered. ${ }^{32}$ Mrs A.E.J. Snyman of Bulawayo described the terrible sight of the murder scene succinctly:

They stabbed Fourie to death - undressed him completely and hung him on a tree. Two little girls were stabbed to death and dragged away. They nailed up a six-month old (little girl) in a box in front of her mother, who thereafter died in an axe murder. ${ }^{33}$ 
The bodies were buried after being discovered by the Gwelo Patrol. Rev A.A. Louw, who came to Rhodesia as an Afrikaner missionary, described the terror of the violence. He related that even an evangelist was murdered and another's house was burnt down by attacking Matabele. ${ }^{34}$

\section{Privations in the "Dutch laagers"}

Meanwhile great battles and reciprocal attacks raged across Rhodesia. In the early stages of the rebellion, the British troops were for the most part put on the defence and for this reason, laagers were formed in the largest towns to act as a defence mechanism for the citizens. English and Afrikaans whites were sternly entreated to seek refuge against possible attacks in the laagers. In most towns, separate laagers were formed on the grounds of cultural ethnicity, that is to say socalled English and Boer laagers. It is noteworthy that, even in times of war, the objective was to maintain separate group identities. The largest laagers were in Bulawayo, including the English laager at the market building and that of the Afrikaners, which was situated at the town's railway station and reservoirs. ${ }^{35}$

According to tradition and narratives relating to the ordeals and privations suffered by Afrikaners, the general conditions within the laagers were appalling. Rev Louw described the state of health and food supply of the community in the laager as utterly wretched. Because of the extremes of the day and night temperatures, the inmates of the laagers suffered various fevers. Many were incapable of performing

services. Food became extremely scarce, so that rationing was introduced. ${ }^{36}$ Common provisions such as coffee, rice, flour and salt were at a premium, although the supply of meat was abundant. D.Q. Campbell also related that inmates often had to eat the meat of cattle suffering from rinderpest in order to stay alive. ${ }^{37}$

The influx of so many whites caused enormous crowding in the laagers. J. Schröder, who was an eyewitness of conditions in the Boer laager in Bulawayo, conveyed his impressions of the increasing numbers of Afrikaners in a confidential report to one Dr Leyds. According to Schröder, he had met a number of Afrikaner families, viz. K.H. Prinsloo and his entire family, the Ferreiras, Greefs, Van der Merwes, Bothas, Esterhuisens, Van Nesgens and many Transvaal families, as well as a number of farmers from the Free State and Cape Colony. Schröder also described the suffering and misery of these inmates: "They exist in abject poverty. Their homes have been burnt down, they have been robbed of everything by the [black people] and they have hardly any clothes on their backs." 38 
According to the 1896 Bulawayo census, it was calculated that there were about 280 Afrikaners in the Bulawayo laager. The census differentiated between the laagers and the population of the "Dutch laager" was set out cryptically. ${ }^{39}$ The census report was published on 22 April 1896. A statistical analysis of the information indicates that there were about 140 male inmates and 109 children present in the laager. Only 31 Afrikaner women were counted. From the foregoing information, it appears that there was a considerable dearth of Afrikaner women, particularly when compared to the larger presence of English-speaking whites, who numbered 1251 (645 men, 260 women and 346 children) in the main laager. ${ }^{40}$

In Salisbury, a number of Afrikaners gathered near the prison grounds to form a laager. G.H. Tanser in his book, A scantling of time: The story of Salisbury, mentioned the presence of a "chaotic collection of vociferous burghers" in Salisbury. He explained that after the Afrikaners had entered the laager with their wagons and possessions, they insisted on keeping their draft animals in the laager. ${ }^{41}$ Inmates were terrified because of the constant rumours of murders in the vicinity of Salisbury. "Children cried, mothers wept and men swore as they sorted out their belongings. A strong south-easterly wind blew and raised clouds of red dust."42

T.C. de Klerk, an inmate of the Enkeldoorn laager, related that on the same day that Mr G. Swartz's wife was buried at Allenby, he received the shocking news that he had to hasten to the Enkeldoorn laager. De Klerk said sadly that he was still standing next to the open grave when they were asked by Tommy Ferreira to leave for the Enkeldoorn laager urgently. They would spend about three months in the laager. ${ }^{43}$ Gert Stefanus Kok, another inmate of the Enkeldoorn laager, mentioned false alarms which were spread in Bulawayo as a precautionary drill exercise, but which had the effect of alarming the inmates. ${ }^{44}$ In Umtali, a seven-pounder machinegun was erected in front of the post office and used to warn citizens of possible attacks. The local white population in the vicinity of Umtali was summoned and protected in a laager set up in the Masonic Hotel and even in the prison. ${ }^{45}$

Donald Campbell declared that they and other Afrikaners in the Enkeldoorn laager witnessed many trials and prosecutions of captured Matabele. Campbell witnessed three Matabele spies around Bulawayo being captured, sentenced to death and publicly hanged at the cemetery. ${ }^{46}$

No devastating attacks were carried out against the various town laagers during the course of the Matabele rebellion, but the Afrikaners and the English experienced the acrimony of the rebellion indirectly. The tide would turn against the 
Matabele after three months, following which the inmates of the laagers would leave the laagers to return to their homes. Cecil John Rhodes managed, after successful peace talks with the Matabele chiefs in the Matopos, to persuade them to reach a peace agreement.

Although the peace was maintained, a completely unexpected Mashona rebellion under the leadership of Nyanda and Kaguli broke out. ${ }^{47}$ Most probably, the Mwari priests influenced the decision of these leaders, because in military terms it would be the last attempt to drive away the whites. According to an article by D.N. Beach on the relations between the Afrikaners and the Mashona in the Enkeldoorn district, there was no indication that the Afrikaners had any particular part in the disquiet of the Mashona. There was also no connection between the occupation of farms and the rebellion as such. ${ }^{48}$

An order was given to murder all the whites in the Mazoe district and seize their possessions for the chiefs. Homesteads and barns were burnt down and a few murders were reported, although the Mashona were unable to overpower the Rhodesian military forces, among others the Mazoe patrol. ${ }^{49}$ Two Afrikaners, Jan Greyling and a Mrs Heine, were murdered in the environs of Salisbury. During the vicissitudes of the Mazoe patrol, three Afrikaners, Christiaan McGeer, one Jacobs and one Van Staden fell, while Hermanus Berry was wounded on the battlefield. ${ }^{50}$ In due course, however, the Mashona were brought under control, and in October 1897, Nyanda and Kaguli surrendered. Thereafter any possibility of further rebellion by indigenous population groups in Rhodesia came to a final end. ${ }^{51}$

\section{The Afrikander Volunteer Corps}

Major conventional battles took place in Rhodesia during the Matabele rebellion in which, among others, a considerable Afrikaner military detachment was involved. This military unit was officially known as the Afrikander Volunteer Corps (or colloquially simply as the Afrikaner Corps). The colonial main body was the Matabeleland Field Force, which made a significant contribution under the administrative control of the BSAC. The Afrikaner Corps, which resorted under the Matabeleland Field Force, also contributed significantly. The Corps not only took a stand in defence positions as auxiliaries, but also played an active part in important battles. 


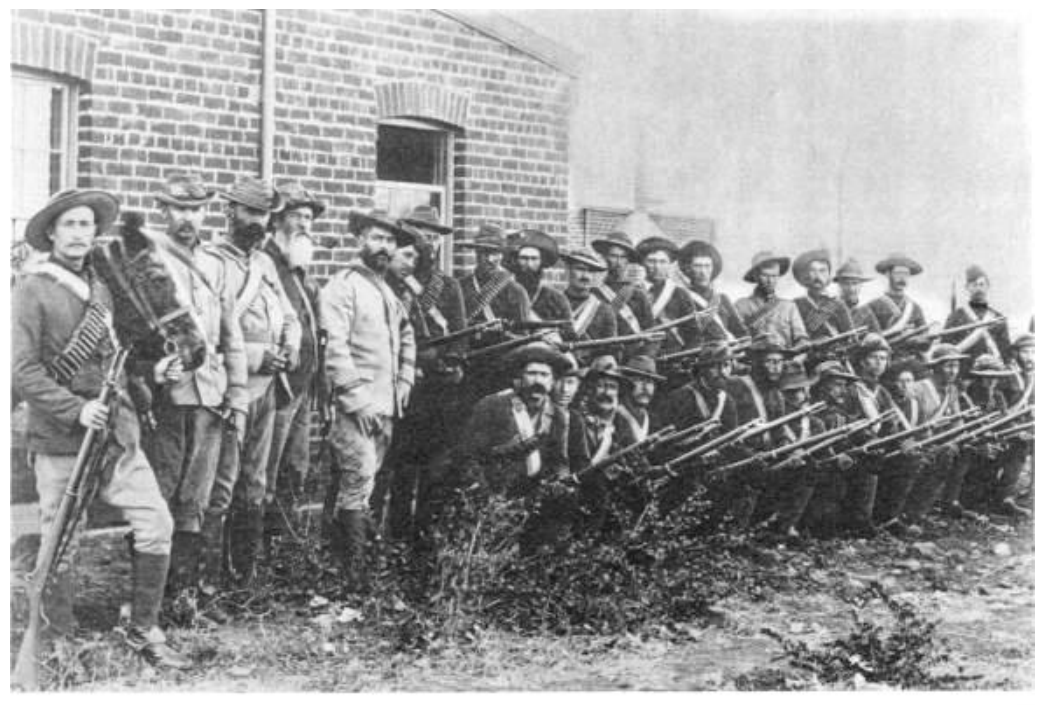

The Afrikander Corps.

Figure 1. Afrikaner Corps. ${ }^{52}$

The military composition of the Afrikaner Corps consisted of experienced, trained members of armed forces who had gradually immigrated to Rhodesia from the Boer Republics and other South African British colonies, as well as inexperienced Afrikaners who were seeking a better life by voluntarily joining the armed forces. On 27 March 1896, the Chief of Staff, General Digby Willoughby, issued a communication setting out the composition of the Afrikaner leadership in the Afrikaner Corps.

According to the communication, 200 Afrikaners had joined the Afrikaner Corps. About thirteen Afrikaners were appointed respectively as military officers, captains or lieutenants in the commanding positions. W.H. van Rensburg was appointed commandant, and Ponty C. van Niekerk, "field captain" in the highest ranks of the corps. Captains M. Attwell, T. Patterick, C. Cohen, one Barnard, P.H. van Niekerk and Lieutenants T. Meisle, Flemming, J. Hannay and J. van Niekerk were appointed respectively in the company subdivisions. Captain J.W. Colenbrander, the prominent leading figure in the Afrikaner Corps, was appointed supreme chief of a military division, the Colonial Coloured Boys, and one Captain Methuen was promoted to commander of the C Company subdivision of the Afrikaner Corps. ${ }^{53}$ 
It is noteworthy that the British supreme command in Rhodesia did not hesitate about the immediate admission and incorporation of volunteer Afrikaners in the Afrikaner Corps. It is worth mentioning that the British opinion of the Boers' unique fighting spirit and tough generalship took root, especially after the Battle of Majuba and the Jameson Raid, in the period before the Matabele rebellion. Mrs A.E.J. Snyman, in a comprehensive letter regarding Commandant Willem van Rensburg, described the pugnacity among the Afrikaners as follows: "P. van Niekerk was really the man. He was a good soldier. The English could have done nothing without that group of Boers. Old man Van Rensburg also fought well."54

By April 1896, Captain Brand would have been acting as official commander of the Afrikaner Corps. Brand was later lauded by the British for his tenacity and bravery. Colonel Napier, who was in command of the troops, for example, sent Captains Van Niekerk and W.H. van Rensburg out to oust the Matabele outside Bulawayo.

Relief campaigns and reconnaissance of enemy positions were also undertaken. D.Q. Campbell related that he voluntarily left the Bulawayo laager to join the unit of Capt. Van Rensburg. Campbell disclosed that at one time 30 men were trapped in a house near Inyati, so that one Capt. Pattenrick mustered 60 volunteers including Campbell, to go and relieve them. ${ }^{55}$

Two important battles, during which the Afrikaner Corps played a decisive role in the eventual outcome of the battles, were in the rearguard actions at Tuli Road and the Battle of Colenbrander's Farm.

\section{The rearguard actions at Tuli Road}

The first major confrontation between the Afrikaner Corps and the Matabele forces took place on 10 April 1896 at Tuli Road. Fifty mounted men of the Afrikaner Corps under the command of Capt. Brand together with the Bulawayo Field Force were mustered to bring a group of whites from Manzi-Izama in the Gwanda district to safety in the Bulawayo laagers. ${ }^{56}$ Capt. Brand was instrumental in the reconnoitring of the route and after instructions had been issued to Capt. Van Niekerk, the combined unit departed on 2 April 1896.

Geographically speaking, the group had to undertake a journey of almost 80 miles (approximately $128 \mathrm{~km}$ ) from Tuli Road through a small nek surrounded on both sides by steep kopjes. ${ }^{57}$ On the return journey, the Matabele rebels lay in wait on the slopes of the kopjes and attacked. Soon a major rearguard battle occurred. 
Capt. Brand fought back determinedly with the Afrikaner Corps on the right-hand side of Tuli Road, while the Matabele made an inexplicable attempt to attack the position on three sides simultaneously. A bloody battle ensued when the devastating force of the Maxim machine-gun was used against the attacking Matabele.

Battles spread out to an open terrain where Capt. Brand became engaged in fierce battles. The Rhodesian Weekly Review reported that about 2000 Matabele, some armed with firearms, had surrounded Capt. Brand's battalion in a pincer movement and inflicted heavy losses. The report sketched the following picture of the battle:

The fate of wounded is the largest yet brought in and totals 20 , one or two of whom have died since of their injuries ... There was no question as to the pluck and endurance [of Capt. Brand] throughout the engagement. He had several narrow escapes. His horse was killed under him. Towards the close of the day, outnumbered by surrounding enemies holding a good position, with at least a quarter of the men disabled and half the horses shot, Captain Brand sent a dispatch in asking for help and ammunition. ${ }^{58}$

Conditions were critical. The turning point in the battle came, however, when Capt. Van Niekerk launched a counter-attack against the retreating Matabele. Sections of the Afrikaner Corps took up position in the rearguard and cornered the fleeing Matabele who were trying to escape. ${ }^{59}$ Large numbers of Matabele were killed and the rearguard battles soon degenerated into a rout.

Eventually the Matabele fell back with a battered army. On the side of the whites, five men fell, 15 were wounded and about 30 horses perished. ${ }^{60}$ On the side of the Matabele, 150 were killed and twice as many were wounded. After the battle, Cecil John Rhodes expressed his gratitude to Capt. Brand and the Afrikaner Corps: “... we desire you to notify to Capt. Brand, Capt. Van Rensburg and the men under them, our high appreciation and admiration for the plucky and heroic manner in which they behaved against the Matabele."61 


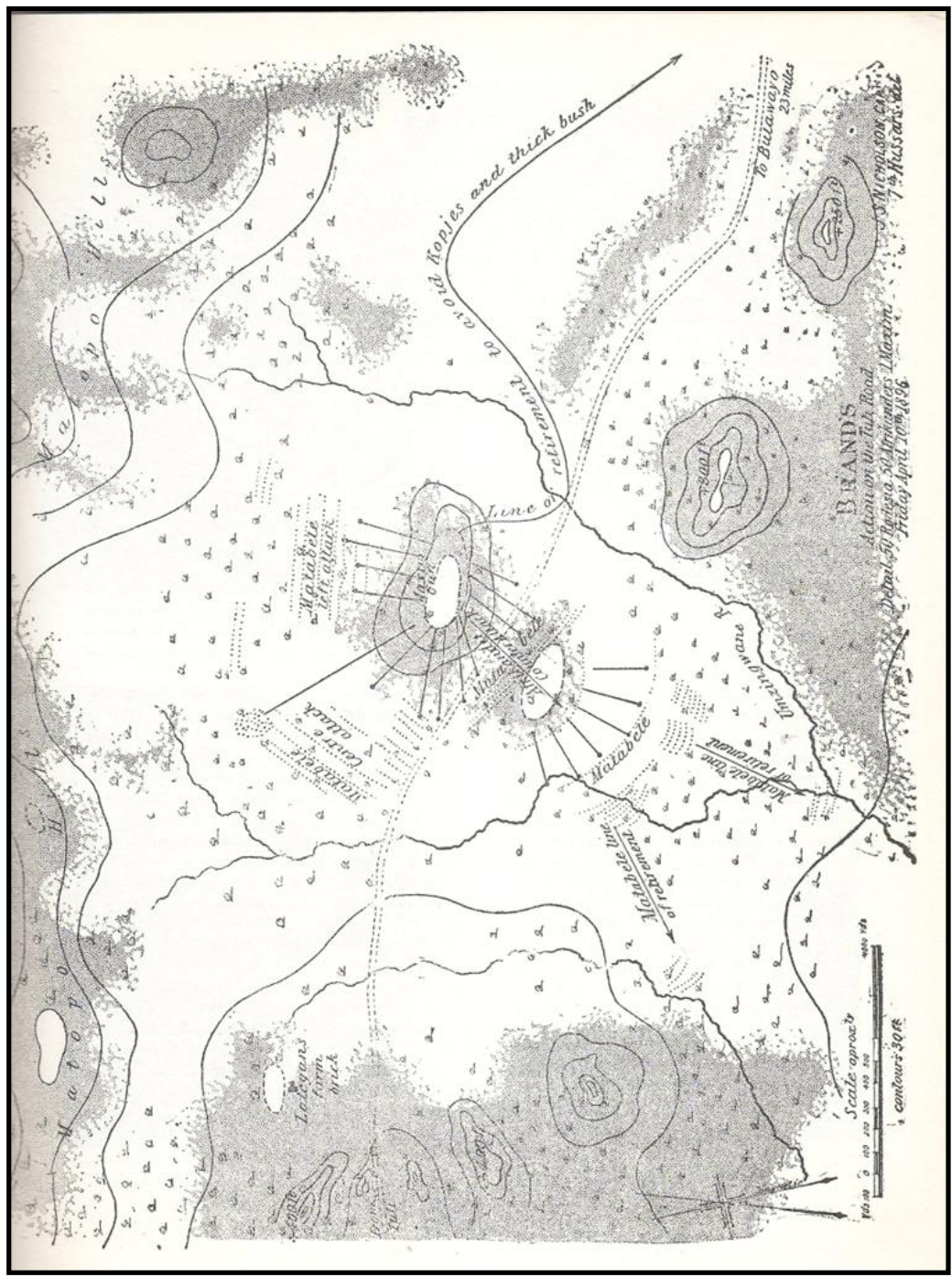

Figure 2. Map depicting the rearguard actions at Tuli Road. ${ }^{62}$ 


\section{The battle at Colenbrander's farm}

The second battle in which the Afrikaner Corps played an active part was in a clash with the Matabele in the close proximity of the farm belonging to J.W. Colenbrander. After rumours of a mighty Matabele military rally at the Umgusa River, a large column of British colonial forces, supported by friendly black soldiers as well as the Afrikaner Corps was mustered in order to stop the possible movements of the Matabele. On 25 April 1896, the column departed southwards on the Salisbury Road with the Grey Scouts in the vanguard and the Afrikaner Corps taking up the left-hand position. ${ }^{63}$

In their advance, the column spotted enemy forces near Colenbrander's homestead and consequently the Grey Scouts, which were raised by Capt. George Grey, immediately took up position on a steeper kopje (See Figure 3). From there, the great numbers of Matabele, who were trying to lead the column into an ambush, were subjected to rifle fire. Because of Capt. Grey's military tactics, it was decided to equip Colenbrander's homestead as a safety and defence stronghold. The Matabele, some of whom were armed with firearms, kept up an incessant barrage on the stronghold from the dense bush. As in the case of the rearguard battles at Tuli Road, the deadly weapons of the column once more led to a terrible massacre.

On the left side of the column, where the Afrikaner Corps had taken up position against a hillock, the corps made a decisive contribution in opposing the Matabele force, which was charging anew. The Matabele gunfire was much more effective, but the Afrikaner Corps succeeded in gaining the upper hand in the fierce combat. Meanwhile the troops of Capt. Grey and one Dawson had joined the Afrikaner Corps to administer the death-blow to the crumbling Matabele army. Although 76 Matabele fallen were counted in the river area, the total loss of lives was much greater. ${ }^{64}$ It was a definitive victory for the colonial forces and the Afrikaner Corps, although they were battle-weary. There was only one wounded among the Afrikaners, namely Johannes Christiaan Botha. ${ }^{65}$ 


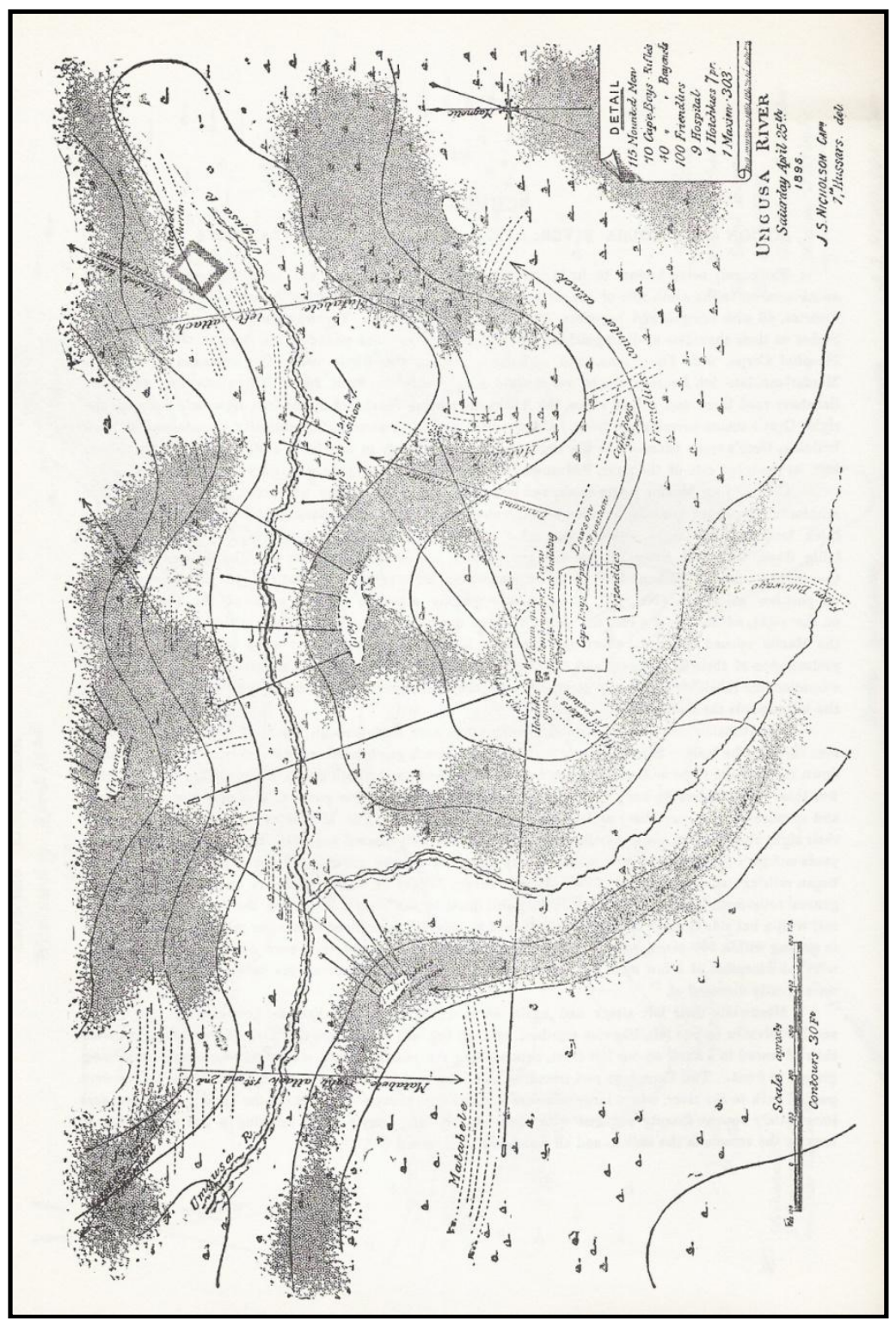

Figure 3. Map depicting the battle at Colenbrander's farm. ${ }^{66}$ 


\section{Recognition and equal rights}

Even before the end of the rebellion in October 1896, a short-lived vexing question arose among the British rulers in Rhodesia as to the full recognition of the Afrikaner Corps. However, Cecil John Rhodes resolved this question in a letter in a well-considered manner. Rhodes expressed his view of the duty the Afrikaners performed in the suppression of the Matabele rebellion of $1896^{6067}$ and thanked them for their participation beside their "... English comrades as if they too were English born". 68

In Rhodes' report back, he expressed his regret on behalf of Joseph Chamberlain, the British colonial secretary that a more comprehensive list of names of Afrikaners with distinction status was not presented to the British Royal House. Notwithstanding the fact that Chamberlain was well aware of the excellent service rendered by the Afrikaner Corps, the London Gazette later made only inconspicuous mention of the Afrikaner Corps. Sir F. Carrington later declared that Capt. Van Niekerk, among others, should have been decorated for his bravery. ${ }^{69}$

D.Q. Campbell related that Rhodes indeed tried to reward members of the Afrikaner Corps with offers of farms on the Gwani River. ${ }^{70}$ Seen as a whole, the outcome of the Matabele rebellion was advantageous to the Afrikaners and the trust of the British in Rhodesia in them was enhanced. The BSAC published a detailed exposition of the casualties during the Matabeleland rebellion in which the Afrikaner Corp was pertinently referred to. ${ }^{71}$

According to the casualty list in Matabeleland, five Afrikaner Corps soldiers, R.A. Baker, G.W. Boyes, J.J. Heineman, W. Cornelius van Zyl and H. Montgomery, died on the battlefield. Two soldiers, A. Anderson and John Celliers, died soon after being wounded. A further four soldiers, namely Sergeant-Major T. Haden, Eziah Michael Terblanche, Johannes Christiaan Botha and Jacobus Combrink were wounded in battle. The deaths of three Afrikaner Corps members owing to unrelated causes were reported by the Bulawayo Hospital. Stephen Ferreira died of fever after a firearm accident. C. Hiscock died of jaundice and pneumonia, and W.H. Wallace succumbed to dysentery. ${ }^{72}$

About three and a half years of peaceful co-existence in Rhodesia followed after the conclusion of the Matabele and Mashona rebellions. The British consolidation of might and imperialistic expansion went from strength to strength. Mainly as a result of Cecil John Rhodes' controversial position in connection with 
the failed Jameson Raid, it appeared that he wanted to maintain the support of the Afrikaners in Rhodesia.

In spite of the Afrikaners' successful participation in the suppression of the rebellions, J. Sinclair, editor of the Chronicle noted that an antagonistic attitude had nevertheless arisen against Rhodes on the part of a few Afrikaners. It revolved around small compensation claims and recognition. Sinclair emphasised the following:

... still there are few men in the Afrikander Corps today who would not defend him ... and bitterly resent the interference of those who would throw the shadow of censure on one who they rightfully consider the friend of every Africander. ${ }^{73}$

Rhodes evidently thought it fit to promise equal rights to all Afrikaners within the territory of Rhodesia, which could likewise serve as rightful compensation for them. In 1897, during a speech at a banquet in Gwelo, Rhodes gave his promise to both English and Afrikaners: "Equal rights for every white man south of the Zambezi."74

This fundamental point of view regarding equal rights in turn gave rise to the notion among Afrikaners that they would, as a separate population group and minority, be indemnified against possible intrusion or deliberate British domination. Afrikaners in Rhodesia interpreted it as an entrenchment of their language and culture. According to P.J. van der Merwe, the question of equal rights could, however, have been misinterpreted. Afrikaners assumed that they would be completely on a par with the English-speaking Rhodesians, but that -

... on the side of the English the theory of equal rights [was] interpreted in such a way that the Englishman would have the right to retain his language and remain himself, and that the Boer would have the privilege of learning English and becoming an Englishman, and that the right to be an Englishman and to become one were one and the same." 75

Ideologically speaking, Rhodes' promise was based on the liberal democracy, which was aimed at bringing about greater cooperation and freedom between the white ethnic groups. In a report in the Chronicle of 1898, the view was postulated that the paths of the two groups had crossed and that they had both equally striven for a "proud destiny" in Rhodesia. 
In this land the two great white races of Southern Africa should find their meeting place, and the chief aim of any publicist and politician should be to prevent any favoured policy to Dutch and English. We do not want any Afrikander or Hollander clique, and Englishmen do not need any special privileges. All should live under the same laws. Let it be Rhodesia's proud destiny to rewrite the two white races of South Africa." 76

Nevertheless, Rhodes, by means of his promise to Afrikaners, although relatively vaguely defined, persuaded them to demonstrate their loyalty to the British supreme authority in Rhodesia.

\section{Conclusion}

The first ten years after the inception of Rhodesia are regarded as the most tumultuous time in the history of the country. On the whole, the local wars and rebellions in Rhodesia had a direct effect on the Afrikaner minority population. Many Afrikaners found themselves in the crossfire of conflicts, as in the case of the Matabele war of 1893, while others fought and died on the side of the British. Compared to similar military units, it can be stressed that the Afrikaner Corps may be regarded as an auxiliary force, as the Afrikaner volunteers regarded it necessary to lend support to the dominant colonial British forces.

The Afrikaner volunteers undoubtedly considered their involvement in the corps as an obligation towards the protection of their families residing in the countryside, as well as a gesture of loyalty to the British colonial forces in Rhodesia. The motivation of Afrikaners could therefore be attributed to causes, which arose from necessity and choice rather than by means of coercion by the British authorities. The role of the Afrikander Volunteer Corps during the Matabele rebellion of 1896 was nevertheless decisive. They contributed markedly in two of the important battles and eventually succeeded in tilting the balance of these battles. Aided by their advanced weaponry they inflicted heavy casualties on the Matabele and forced them onto the defensive.

Despite their military victories and achievements, it is a presumption that their very presence as Afrikaners, reminded as they were of their past hostilities towards and struggle against the British forces during the First Anglo-Boer War in South Africa, created a stigma against Afrikaners as a group. The lack of recognition and equal rights towards these Afrikaner volunteers after the death of Rhodes 
supports this argument. In the initial phases of the foundation of Rhodesia, British confidence in the Afrikaners in Rhodesia was largely strengthened with great gratitude and respect because of their loyalty to Cecil John Rhodes. Although there seemed to be confidence in Afrikaners as fellow Rhodesians, the British authorities in Rhodesia became increasingly suspicious of and ignorant about Afrikaners and their pleas for equal rights as a minority group in Rhodesia during the first decades of the twentieth century.

${ }^{1}$ Gustav Hendrich obtained the degree PhD in History from Stellenbosch University for a dissertation entitled Die geskiedenis van die Afrikaners in Rhodesië (1890-1980) [The history of the Afrikaners in Rhodesia (1890-1980)]. Since 1890, Afrikaners from South Africa, mostly as a result of the search for improved living conditions and job opportunities, gradually found their way to the territory north of the Limpopo River. The organised and individual treks and the sporadic movement of Afrikaner immigrants to Rhodesia would lay the foundations of a self-supporting, though geographically straggling, population group.

${ }^{2}$ Iemhoff, WGJ. Oorlog, dienstplicht, dienstweigering. Baarn: Het Wereldvenster, 1966, 117-118.

${ }^{3}$ Ferriter, D. The transformation of Ireland: 1900-2000. London: Profile, 2004, 122; Coogan, TP. Ireland since the rising. New York: Praeger, 1966, 15.

${ }^{4}$ Hindus, M. The Cossacks. London: Collins, 1946, 317.

${ }^{5}$ Bethell, N. The last secret: Forcible repatriation to Russia 1944-7. London: Futura, 1974, 106-107.

${ }^{6}$ Petersen, W. Japanese Americans: Oppression and success. New York: Random House, $1971,87$.

${ }^{7}$ McDowall, D. A modern history of the Kurds. London: IB Tauris, 1996, 105-106; Natali, D. The Kurds and the state: Evolving national identity in Iraq, Turkey, and Iran. New York: Syracuse University Press, 2005, 71.

8 "Regulations for the Volunteer Force". Colonial Forces Act No. 32 of 1892, 5-7.

${ }^{9}$ Colonial Forces Act No. 32 of 1892, with Rules and Regulations framed under the Act. Cape Town: WA Richards, Government Printers, 1892, 7.

${ }^{10}$ Ibid., p. 10

${ }^{11}$ Hurst, GT. Short history of the volunteer regiments of Natal and East Griqualand: Past and present. Durban: Knox, 1945, 1-3.

${ }^{12}$ Ibid., pp. 43-45.

${ }^{13}$ Crosby, E. The real white man's burden. London: Funk and Wagnalls, 1902, 3235.

${ }^{14}$ Gann, LH. A history of Southern Rhodesia: Early days to 1934. London: Chatto and Windus, 1965.

${ }^{15}$ Baxter, TW \& Turner, RWS. Rhodesian epic. London: Timmins, 1966, 116.

${ }^{16}$ Colquhoun, AR. Matabeleland: The war, and our position in South Africa. London: Leadenhall, 1893, 109. 
${ }^{17}$ Di Afrikaanse Patriot, 25 October 1894.

${ }^{18}$ Western Cape Provincial Archives and Records Centre (hereafter WCPA), PJ van der Merwe Collection A2599, no. 248. Pamflette, Dorey, A. The Victoria incident and the Anglo-Matabele War of 1893: A study of early colonization in Central Africa, and the African response, 1.

${ }^{19}$ WCPA, PJ van der Merwe Collection A2599, no. 248, Pamflette, Occupation of Matabeleland Souvenir, 125. Commandant Pieter Johannes Raaff also participated in the Anglo-Zulu War of 1879. After the occupation of Mashonaland he was appointed as Magistrate of Fort Tuli.

${ }^{20}$ WCPA, PJ van der Merwe Collection A2599, no. 161, Onderhoude/verklarings van pioneers, Hoffman, JP. Geskiedenis van Rhodesië, 12.

${ }^{21}$ WCPA, PJ van der Merwe Collection A2599, no. 147, Afrikaners in Rhodesië, Pionierskolonne onderhoude, Du Plessis, JL, Enkeldoorn, 5.

${ }^{22}$ WCPA, PJ van der Merwe Collection A2599, no. 248, Pamflette, Occupation of Matabeleland Souvenir, 23.

${ }^{23}$ WCPA, PJ van der Merwe Collection A2599, no. 147, Afrikaners in Rhodesië, Pionierskolonne onderhoude, Du Plessis, JL, Enkeldoorn, 5.

${ }^{24}$ WCPA, PJ van der Merwe Collection A2599, no. 248: Pamflette, Dorey op. cit., p. 23.

${ }^{25}$ Baxter \& Turner op. cit., p. 117.

${ }^{26}$ Hunter, G, Farren, L \& Farren, A. Voices of Zimbabwe: The pain. The courage. The hope. Johannesburg: Covos, 2001, 2.

${ }^{27}$ Weiss, R. Zimbabwe and the new elite. London: British Academic Press, 1994, 22-23.

${ }^{28}$ Schmidt, E. Peasants, traders and wives: Shona women in the history of Zimbabwe, 1870-1939. London: James Curry, 1992, 42.

${ }^{29}$ Weiss op. cit., p. 23.

${ }^{30}$ WCPA, PJ van der Merwe Collection A2599, no. 110, Afrikaner Korps, $R W$ Review. 2 May 1896. "Afrikaners vermis".

${ }^{31}$ WCPA, PJ van der Merwe Collection A2599, no. 110: Afrikaner Korps, $R W$ Review. 2 May 1896. "Afrikaners vermis".

32 Anon. "The '96 rebellions". [The British South Africa Company Reports on Native Disturbances in Rhodesia, 1896-7], p. 47.

${ }^{33}$ WCPA, PJ van der Merwe Collection A2599, no. 110, Afrikaner Korps, Snyman, AEJ (Bulawayo) oor Komdt. Willem van Rensburg, 1-2.

${ }^{34}$ Louw, AA. Die môrester in Mashonaland. Stellenbosch: CSV Boekhandel, n.d., 108.

${ }^{35}$ Ransford, O. Bulawayo: Historical battleground of Rhodesia. Cape Town: AA Balkema, 1968, 89.

${ }^{36}$ Louw op. cit., p. 110.

${ }^{37}$ WCPA, PJ van der Merwe Collection A2599, no. 161, Onderhoude/verklarings van pioneers. Verklaring van Donald Quertin Campbell, 20 June 1939, 4.

${ }^{38}$ WCPA, PJ van der Merwe Collection A2599, no. 110, Afrikaner Korps, Schröder J. Confidensiele rapport aan Dr Leyds, Leyd Argief 1896, Band 630. 
${ }^{39}$ WCPA, PJ van der Merwe Collection A2599, no. 110, Afrikaner Korps, $R W$

40 Ibid. Review. 25 April 1896. Census of Bulawayo.

${ }^{41}$ Tanser, GH. A scantling of time: The story of Salisbury, Rhodesia (1890-1900). 42 Ibid. Salisbury: Pioneer Head, 1974, 159.

${ }^{43}$ WCPA, PJ van der Merwe Collection A2599, no. 161, Onderhoude/verklarings van pioniers, TC de Klerk - Mnr. Vermaak, 5 September 1939, 1-2.

${ }^{44}$ WCPA, PJ van der Merwe Collection A2599, no. 161, Onderhoude/verklarings van pioniers, Verklaring van Gert Stefanus Kok, 2.

${ }^{45}$ WCPA, PJ van der Merwe Collection A2599, no. 252, Koerantknipsels, The Umtali Post Jubilee supplement. 15 August 1950. "When the gun fired everyone ran into the laager".

${ }^{46}$ WCPA, PJ van der Merwe Collection A2599, no. 161, Onderhoude/verklarings van pioniers. Verklaring van Donald Quertin Campbell, 20 June 1939, 4.

${ }^{47}$ Baxter \& Turner op. cit., p. 145.

${ }^{48}$ Beach, DN. "Afrikaner and Shona settlement in the Enkeldoorn area, 18901900”. Zambesia II/2. 1970. 32.

${ }^{49}$ Baxter \& Turner op. cit., p. 145.

${ }^{50}$ WCPA, PJ van der Merwe Collection A2599, no. 160, Onderhoude: getikte uittreksels. Rhodesië na 1890, Mazoe-patrollie, 1896.

${ }^{51}$ Baxter \& Turner op. cit., p. 145.

52 Anon: The '96 Rebellions. [The British South Africa Company reports on native disturbances in Rhodesia, 1896-7], p. 47.

${ }^{53}$ WCPA, PJ van der Merwe Collection A2599, no. 110, Afrikaner Korps, $R W$ Review. 28 March 1896. Africander Volunteer Corps, Notice 4.

${ }^{54}$ WCPA, PJ van der Merwe Collection A2599, no. 110, Afrikaner Korps, Snyman, AEJ (Bulawayo) oor Komdt. Willem van Rensburg, 7-8.

${ }^{55}$ WCPA, PJ van der Merwe Collection A2599, no. 161, Onderhoude/verklarings van pioneers. Verklaring van Donald Quertin Campbell, 20 June 1939, 3.

${ }^{56}$ Anon op. cit., p. 28.

${ }^{57}$ Ibid.

${ }^{58}$ WCPA, PJ van der Merwe Collection A2599, no. 110, Afrikaner Korps, $R W$ Review. 18 April 1896.

${ }^{59}$ Anon op. cit., p. 28.

${ }^{60}$ Ibid.

${ }^{61}$ WCPA, PJ van der Merwe Collection A2599, no. 110, Afrikaner Korps, $R W$ Review. 25 April 1896. Official Reports.

62 Anon: The '96 Rebellions. [The British South Africa Company reports on native disturbances in Rhodesia, 1896-7], p. 29.)

${ }^{63}$ Anon op. cit., p. 35.

${ }^{64}$ Ibid.

${ }^{65}$ Ibid. 
${ }^{66}$ Anon: The '96 Rebellions. [The British South Africa Company reports on native disturbances in Rhodesia, 1896-7], p. 36.

${ }^{67}$ WCPA, PJ van der Merwe Collection A2599, no. 110, Afrikaner Korps, Colonial Office (LO 3/1/50), BSAC, 29 June 1897.

${ }^{68}$ Maquire, JR. Cecil Rhodes: A biography and appreciation. London: Macmillan, $1897,64$.

${ }^{69}$ WCPA, PJ van der Merwe Collection A2599, no. 110, Afrikaner Korps, Colonial Office (LO 3/1/50), BSAC, 29 June 1897.

${ }^{70}$ WCPA, PJ van der Merwe Collection A2599, no. 161, Onderhoude/verklarings van pioneers. Verklaring van Donald Quertin Campbell, 20 June 1939, 5.

${ }^{71}$ Anon op. cit., pp. 40-45.

${ }^{72}$ Ibid.

${ }^{73}$ WCPA, PJ van der Merwe Collection A2599, no. 147, Sinclair, J, Afrikaners in Rhodesië, Rhodes en die Afrikaners. Chronicle. 8 July 1896.

${ }^{74}$ WCPA, PJ van der Merwe Collection A2599, no. 147, Afrikaners in Rhodesië, Rhodes en die Afrikaners. Chronicle. 26 August 1897, Rhodes speech.

${ }^{75}$ WCPA, PJ van der Merwe Collection A2599, no. 147, Van der Merwe, PJ, Afrikaners in Rhodesië, Houding teenoor Afrikaners. "Gelyke regte".

${ }^{76}$ WCPA, PJ van der Merwe Collection A2599, no. 147, Afrikaners in Rhodesië, Houding teenoor Afrikaners. Chronicle. 25 May 1898. "The parting of the ways". 